\title{
Marketing strategy applied in the environment of an international company
}

\author{
David Vrtana ${ }^{1, *}$ Martina Gogolova ${ }^{2}$ \\ 1,2 University of Zilina, Faculty of Operation and Economics of Transport and Communication, \\ Department of Economics, 01023 Zilina, Slovak Republic
}

\begin{abstract}
The escalating trend of globalization makes enterprises increasingly adapt to the international environment. This can be seen as very demanding and diverse. However, there are many multinational corporations currently being active worldwide. Multicultural differences, either the impacts of the economic, political or legal environment can significantly affect the business scope of enterprises in a global environment. For example, gaining and maintaining a competitive advantage worldwide can be an advantage of global action. The subject of the article is an analysis of a company BHP Biliton, which operations extend to twelve countries around the world spreading across all continents. The company also focuses on current global trends. The articles is focused mainly on the slowdown in economic development, where BHP Billiton has a corporate program in place. The company also tries to tackle the global climate change problems by cutting emissions. The subject of the analytical part of the article is to analyze the competitive position by means of the Porter model on the basis of available data about the BHP Billiton company. Furthermore, Ansoff's matrix is elaborated in the analytical part, which identifies the specific strategy of targeting the company to products or markets. Based on the analyzed and compared data and outputs from BHP Billiton's analysis, the article proposes a more effective way of using a marketing strategy and accepting global trends.
\end{abstract}

\section{Introduction}

The international environment is currently very differentiated. Ruey-Jer Bryan and Danchi claim that the production rate of international companies in the host environment is stronger and more positive than their impact in the domestic market. [1] The authors' statement points out at the importance of differentiation of the activities of an international company on the domestic and foreign markets. According to Rosanna et. innovation and innovative equipment contribute to the foreign martket differentiation as well. [2] In addition to the differentiation of firms in international markets, it is also possible to observe a trend in their competitive position. This decides in the success or failure of the company in a global environment. The strength of a company's competitive position in an

\footnotetext{
* Corresponding author: david.vrtana@fpedas.uniza.sk
} 
international environment can be affected by several factors. One of them, according to Balachandran and Hernandez, is institutional reform that can affect the global economy. [3] Duhaneanu argues that a number of rules apply to the global economy and it is therefore important that companies are able to adapt effectively to the changing conditions. [4] Business models also need to be geared to the perception of competitive position in a global environment. According to Tallman, Luo and Buckley, they can capture the value of a business in a global environment. The authors included increasing the value for the customer and capturing its share, methods for managing, deploying and using critical resources, and integrated processes among the basic elements of the success of the business model in a global environment. Similar opinion is expressed by Kliestikova et. al. $[5,6]$ The perception of the business model can significantly influence the international competitive position of the company. The authors say that the above-mentioned elements of the business model can bring value to global customers. These can be seen as a key to the company's success in a global environment. The subject of the article will be the global mining company BPH Billiton, whose data analysis and results are described in the following chapters.

\section{Methodology: Analysis of organization BHP Billiton company}

One of the companies that has to adapt intensively to the international environment is the English-Australian multinational mining, metal and oil company BHP Billiton. The company's headquarters are in Melbourne and London. BHP Billiton consists of two parent companies, BHP Billiton LImited and BHP Billiton Plc. In relation to its surroundings, the company acts as a dual listed company, which is one economic entity established in Australia. Nowadays, the company has 380 subsidiaries located around the world. Since the company is engaged in the extraction of several raw materials, the organization of these subsidiaries is divided into specialized organizational units that correspond to individual segments. The main organizational unit for petroleum resources is located in Houston, for coal in Brisbane, for iron ore in Perth. The reason for this diversification into individual segments is mainly to be able to effectively manage the extraction of individual commodities. Therefore, the organizational units are thus diversified and are located near a subsidiary that provides the extraction of the particular raw material. Other control centers are placed in the similar way. Subsidiaries are directly subordinated to the parent company where management centrally supplies the management of individual subsidiaries through individual specialized business units. The product portfolio of subsidiaries is differentiated. Each subsidiary or multiple subsidiaries are engaged in the extraction of one of the raw materials that are part of BHP Billiton's product portfolio. At the same time, some subsidiaries provide "office" services for the parent company, manage finances, deal with marketing, accounting and so on.

The subject of BHP Billiton activity is the extraction of iron ore, coal, oil, copper, natural gas, nickel and uranium. It employs an average of 62,000 people in the current global environment. Compared to 2015, this represents an increase of 32,330 employees.

Despite the declining mining of metals and minerals, BHP Billiton is considered one of the successful international companies. Its revenue in 2015 was US \$ 61.2 billion, of which operating income was US \$ 8.67 billion and net income was US \$ 1.91 billion. In 2018, the revenune of US $\$ 43.63$ billion, operating income increased compared to 2015 , an average of US \$ 8.89 billion, reaching 2018 US \$ 17.56 billion. Net income reached US $\$ 4,823$ billion in 2018. [7] 


\subsection{Analysis of product portfolio company}

At the beginning of Chapter 2, it was stated that the company's core business was the extraction of minerals, in particular aluminum, copper, manganese, iron ore, uranium, nickel, silver and titanium. Based on the defined scope of business, the company's product portfolio can be divided into the following mining activities:

a) Aluminum mining - the company is the seventh largest aluminum producer in the world. The portfolio mainly includes bauxite production, alumina refining as well as aluminum metal smelting.

b) Base metal processing - in this portfolio the company includes the processing of copper, silver, lead and zinc.

c) Uranium Extraction - Uranium mining is produced by the company due to its usability for electricity production and copper cathodes are delivered to customers in Europe, Australia and Asia.

d) Nickel mining - the company is the world's fourth largest nickel producer. The portfolio of nickel mining mainly involves the production and sale of Feronickel granules, matt nickel and concentrate.

e) Manganese extraction - this product line will include manganese ore alloys from sites in South Africa and Australia. It is the world's largest manganese alloy production company.

f) Coal mining - the company processes high-quality hard coking coal, which is an essential raw material in steel production. Among other things, the company also produces thermal coal primarily for use in the power generation industry.

g) Other mining - the product line includes the production of titanium minerals, the processing of pure pig iron, zirconium, gold and silver.

In addition to mining, the company also focuses on research, extraction and processing of oil and natural gas. These are called. "Petroleum Business", which includes the production of oil, gas condensate and natural gas liquid (NGL). The oil and gas processing plants are located in the Gulf of Mexico, Australia, the United States and the Republic of Trinidad and Tobago. [7]

Currently, the company does not expand its product portfolio. It focuses mainly on the purchase of various mines for more efficient mining and seeks to create new oil and gas project.

\subsection{Marketing of BHP Billiton}

One of the main activities of BHP Billiton is marketing. It is beeing centrally managed from Singapore. There is an intensive cooperation in managing the company's marketing activities between the parent and the subsidiary. BHP Billiton AG, which currently employs approximately 400 employees, is a subsidiary that provides marketing activities to the parent company. For the parent company BHP Billiton AG, it provides various information, analyzes and reports for demand planning, business presentation, supply chain management, analysis of product portfolio and profit maximization. The reason why the subsidiary became a major organizational unit in marketing is that up to $65 \%$ of BHP Billiton's sales come from Asia. Singapore is close to the key Asian markets and it is suitable for trade and investment. The subsidiary is managed directly by the head office in Melbourne. In Asia, the company has other marketing subsidiaries managed by BHP Billiton AG. This is BHP Billiton Marketing Asia Pte Ltd. and BHP Billiton Freight Singapore Pte Ltd. [9]

The primary goal of the company's marketing activities is to strengthen the link between global operations, the customer segment, and local and global suppliers. For example, the iron ore mined in Australia is sold to customers in China for the purpose of steel producing. 
In this way, there is an international connection between the manufacturing company and the customer segment. Another example could be oil production in the Gulf of Mexico. By exploiting oil in the Gulf of Mexico, the company affects transport infrastructure in the United States. In this case, the international marketing link must be very strong and intense on customers. Therefore, it is necessary to focus on brand building. Kliestikova and Moravcikova argue that in the international context it is possible to draw attention to brand building. If mining is limited in a certain global area, it may affect another area whose economic and economic consequences may have a negative impact on customers' purchasing behavior. Also mentioned Kicova et. al. [10,11,12] One of the most important means of achieving the company's marketing objectives is promotion. The company uses different advertising strategies to apply the promotion. The most common means include television, radio and print advertising.

On the basis of the above mentioned data it is possible to express that the marketing strategy of the company is focused primarily on the needs of customers. These seek to connect the business with the right product to maximize the value of input resources, optimize shipping and distribution costs, and ensure an effective corporate view of commodity markets in a global environment.

\subsection{Analysis of current company strategy}

The sub-chapter defines the company's current strategy, including the identification of regional strategies. The definition of the global strategy is based on the Product / Markets Expansion Matrix.

\section{Product/Markets Expansion Matrix (Ansoff matrix)}

Ansoff's matrix defines four basic strategies for future business growth. The all-cerebral strategies resulting from the Ansoff matrix are shown in Table 2. 1. the Ansoff matrix is effective for strategic planning because it provides a framework for identifying a suitable business strategy for the future. Javalgi, Seyda et al. al argue that building a strategy can boost global growth and business expansion. [13] Based on the authors' knowledge, we decided to process the matrix in the article. Table 1 also indicates the strategy that is appropriate for BHP Billiton.

The main objective of the company is to foster economic growth through individual strategic priorities. The strategic priorities for BHP Billiton are as follows:

a) Be Sustainable - This company's priority focuses primarily on the health, safety and quality of life of employees. The company strives to create an efficient working environment for its employees without any possible risks that could endanger the life or health of employees in any way. Part of the corporate governance approach is to identify and manage all possible fatal and serious risks that could pose an increased risk to employees. The company's goal in this strategic priority is to achieve zero work-related fatalities every year.

b) More productive organization - The purpose of this strategic priority is to increase organizational productivity and more productive ways of working for employees, which should be related to reducing unit costs. Here, the company seeks to encourage its employees to work together and create so-called. "functional perfection." It is this method that helps the company measure operational and financial performance within the business. The company's goal in this strategic priority is to constantly create a responsive environment in which every employee can contribute to improving the company's performance.

c) More efficient capital management - through this priority, the company seeks to maximize return on capital for shareholders. For example, over the past 10 years, the company has returned US \$ 67 billion to shareholders in the form of dividends. All areas in 
which the company manages its cash flow are interconnected. Every decision to allocate capital is tested by the company against various short- and long-term criteria through several different options. The objective in this strategic priority is to optimize net present value, return on capital and internal rate of return and margin.

d) Active management of product portfolio - through this priority, the company seeks to achieve economies of scale and competitive advantage. Our product portfolio is constantly striving to expand and develop new products that should be unrivaled in terms of quality. In expanding its portfolio, the company mainly focuses on iron ore, oil, copper and coal.

From the strategic priorities outlined above, the company is striving to attract new investors through new employee care, creating a comfortable working environment and continually improving, improving and developing new products, thereby pushing for new markets to attract new customers and thus be able to meet all the needs of shareholders through more efficient management of their capital. It is clear from the above that the company is trying to establish itself in new markets for new products. In order for the company to succeed in new markets, it will also need sufficient skilled workforce capable of understanding all the values of the company within its various areas of operation.

Table 1. Ansoff matrix strategies.

\begin{tabular}{|c|c|c|}
\hline Markets/Products & $\begin{array}{c}\text { Existing } \\
\text { Products }\end{array}$ & New Products \\
\hline Existing markets & $\begin{array}{c}\text { Market } \\
\text { Penetration }\end{array}$ & $\begin{array}{c}\text { Product } \\
\text { Develompment }\end{array}$ \\
\hline New markets & $\begin{array}{c}\text { Market } \\
\text { Develompment }\end{array}$ & Diversification \\
\hline
\end{tabular}

\section{Porter's five forces analysis}

The next analysis is Porter's five forces. Model pozostáva z identifikovania piatich síl, ktoré môžu ovplyvňovat' dlhodobú ziskovú prít'ažlivost' trhu alebo trhového segmentu spoločnosti BHP Billiton.

The next analysis is Porter's five forces. The model consists of identifying five forces that may affect the long-term profitable attractiveness of BHP Billiton's market or market segment.

a) Competitive Rivalry is low because of the lack of natural resources on the world market and the current trend is scarce in resources. BHP Billiton currently uses state-of-the-art technology, trained staff, good infrastructure, and the company has the best location in the extraction of natural resources than new emerging competitors.

b) Supplier Power can be identified in the possibility of influencing the supply of materials, energy, transportation. This is a negligible substitute, which increases the bargaining power of suppliers.

c) Buyer Power is low because the company can raise prices due to increasing demand and limited natural resources on the market. By maintaining long-term customer relationships, the company has less impact on price increases.

d) Threat of Substitution is low because there are not many product substitutes on the market. The company can effectively combat any threat of substitutes due to a broad, diversified portfolio of products and assets.

e) Threats of New Entry include factors such as global competition for access to natural resources reserves, retaining qualified staff against competitors, building infrastructure for new development projects and strong industry rivalry between BHP Billiton and the largest competitor, Rio Tinto. 


\section{Results}

The product and market analysis showed that the diversification strategy was the most effective for BHP Billiton.company This means that the company should strive to develop new products to be used in new markets. At present, the company is trying to expand its range of products, especially iron ore, oil, copper, coal, or liquefied natural gas. The diversification strategy also entails risks that may be related to the introduction of a new product in a new - unknown market. The advantage of the strategy is that if new products are adopted in a new market, the company can create a stable situation for the future. Su and Tsang argue that a diversification strategy supports increasing the company's financial performance. [14] It is possible to agree with the authors as new products in new markets lead to an increase in the company's income and consequently to an increase in profits. This means that the diversification strategy is not only related to strengthening the competitive position of the company in the global environment, or strengthening stability, but above all also to increasing the financial performance of the company.

In addition to the general strategy for product and market analysis, it is also possible to focus on BHP Billiton's regional strategies. Oil and natural gas production and processing take place in the US and Australia market environment. The aim of the company within the stated environment is to focus on new material opportunities. The company achieves this goal by conducting continuous surveys where it continually seeks to explore new opportunities for oil and gas extraction and processing. For research purposes, the company uses the latest seismic and geophysical technologies to help find new resources. On the basis of the above, it can be argued that, within the existing market environment, an undertaking seeks to develop and implement new material opportunities for oil and gas processing. In the product and market analysis environment (Ansoff matrix), a product development strategy is being implemented in existing markets. In this case, it is possible to perceive the difference between the general enterprise strategy applied globally and the regional strategy defined for a particular market. In the case of other regional strategies, it is also possible to consider extending global reach to other markets. Tigre claims that the key role of the strategy's success is to quickly adapt to the new region. Based on the author's statement, it is possible to state that, in general, not only general strategies but also regional strategies are important for businesses operating in the international environment, to which businesses should pay close attention.

The second analysis was the Porter's model. It implies that a low-level company is influenced by 3 factors, which are the emergence of new businesses in the market, the threat of substitution products and the bargaining power of customers. The only factor that is significant for the company is the bargaining power of the suppliers. Despite this strength, it can be said that the company has a strong market position. The company can also strengthen its strength by investing activity, whose higher return can ensure ahigher share in the global market. [15] Based on the defined data, it can be said that the marketing strategy is also a key factor for the company. It has an enterprise managed by a central subsidiary. In the marketing strategy, the company should focus primarily on building supplier relationships, customer relations and ultimately on environmental burdens. Its success is also strengthened by brand building, which Krizanova et al. supports. [16] The general marketing strategy is customer oriented and strengthening the company's promotional activities into the international environment. The regional marketing strategy should be focused on building relationships with partners and suppliers in Australia and the USA. Building a successful marketing strategy, according to Loper and Veiga, should be strengthening the brand. 


\section{Discussion}

Based on the found and analyzed data, it can be claimed that the company has built a strong strategic position in the international environment. Despite declining profits, the company intensively exploits all opportunities to find new solutions in product development and intensive promotional policies. To maintain the business in an international environment, I recommend maintaining a strong marketing strategy. It must also include environmental protection the importance of which emphasizes Moravcikova et al. Meilă express a similar view. [17,18] Corallo, Errico et al. al argue that the marketing strategy is value oriented. [19] In this sense, value can be perceived not only in relation to society as a whole, but also directly to customers, suppliers, the environment and the like.

\section{Conclusion}

It is extremely challenging to operate in an international environment. Businesses must take into account a number of factors, from product portfolio supply to marketing strategy implementation. This needs to be aligned with all global activities and activities. Based on the results of the matrices, it can be argued that BHP Billiton has a strong position in the international environment, but the question is whether it can effectively take advantage of all the opportunities offered by the market.

\section{Acknowledgment :}

This paper is an output of scientific project VEGA no. 1/0718/18: The impact of psychographic aspects of pricing on the marketing strategy of companies across products and markets.

\section{References}

1. J. Ruey-Jer Bryan, T. Danchi, The Effect of Institutional Capabilities on EBusiness Firms' International Performance. Management International Review 59, 593-616 (2019)

2. R. Spano, A. Allini, M. Maffei, A. Zampella, Knowledge, innovation, and control towards accountability: a comparative case study. Technology Analysis \& Strategic Management 31, 720-731 (2019)

3. S. Balachandran, E. Hernandez, Do Institutional Reforms Perpetuate or Mitigate the Matthew Effect? Intellectual Property Rights and Access to International Alliances. Strategy Science 4, 151-174 (2019)

4. M. Duhaneanu, Business Strategies Under the Impact of the Rules of Global Commerce. Quality-Acces To Success 19, 29-34 (2018)

5. S. Tallman, Y. Luo, P. Buckley, Business models in global competition. Global Strategy Journal 8, 517-535 (2018)

6. K. Valaskova, J. Kliestikova, A. Krizanova, Consumer Perception of Private Label Products: An Empirical Research. Journal of Competitiveness 10, 149-163 (2018)

7. "Annual Report 2018". BHP. Retrieved $29 \quad$ September 2018. https://www.bhp.com/investor-centre/annual-report-2018/annual-report-2018 online cit. 
8. B. Terence, Company profile BHP Billiton: https://www.thebalance.com/company-profile-bhp-billiton-2340279 (2019) online cit.

9. G. Hubbard, J. Rice, P. Galvin, Strategic Management. (Pearson, Australia, 2015).

10. "Annual Report 2018". BHP. Retrieved 29 September 2018. https://www.bhp.com/investor-centre/annual-report-2018/annual-report-2018 online cit.

11. D. Moravcikova, J. Kliestikova, Brand building with using phygital marketing communication. In: Journal of economics, business and management 5, 148-153 (2017)

12. E. Kicova, P. Kral, K. Janoskova, Proposal for brands communication strategy developed on customer segmentation based on psychological factors and decisionmaking speed in purchasing: case of the automotive industry. Economics and Culture 15, 5-14 (2018)

13. R. G. Javalgi, S. Deligonul, A. Dixit, S. T. Cayusgil, International Market Reentry: A Review and Research Framework. International Business Review 20, 377-393 (2011)

14. W. C. Su, E. W. K. Tsang, Product Diversification and Financial Performance: The Moderating Role of Secondary Stakeholders. Academy of Management Journal 58, 1128-1148 (2015)

15. J. S. Huxley, and M. Sidaoui, Gaining Market Share in Emerging Markets Portfolios by Moderating Extreme Returns: The Case of Peru, Economics, Management, and Financial Markets 13, 37-55 (2017)

16. A. Krizanova, J. Majerova, T. Kliestik, P. Majercak Theoretical Aspects of Brand Building in Seafood Industry. NASE MORE 60, 105-112 (2013)

17. D. Moravcikova, A. Krizanova, A., J. Kliestikova, M. Rypakova, Green Marketing as the Source of the Competitive Advantage of the Business. Sustainability 9 (2017)

18. A. D. Meilă, Sustainable Urban Mobility in the Sharing Economy: Digital Platforms, Collaborative Governance, and Innovative Transportation, Contemporary Readings in Law and Social Justice 10, 130-136 (2018)

19. A. Corallo, F. Errico, M. E. Latino, M. Menegoli, Dynamic Business Models: a Proposed Framework to Overcome the Death Valley. Journal of the Knowledge Economy 10, 1248-1271 (2019) 